\title{
In Memoriam: Professor Nermin Başerer
}

\author{
Obituary \\ Bora Başaran (D), Nesil Keleş Türel (iD \\ Department of Otorhinolaryngology, İstanbul University İstanbul Faculty of Medicine, İstanbul, Turkey
}

ORCID iDs of the authors: B.B. 0000-0003-0546-2848; N.K.T. 0000-0003-1829-8186.

Cite this article as: Bașaran B, Keleș Türel N. In Memoriam: Professor Nermin Başerer. Turk Arch Otorhinolaryngol 2020; 58(2): 71-4.

\section{Corresponding Author:} Bora Başaran, bbasaran@istanbul.edu.tr

Content of this journal is licensed under a Creative Commons Attribution 4.0 International License. Available online at www.turkarchotolaryngol.net cc) (i) $($ )
We lost Nermin Başerer in the intensive care unit of İstanbul University, İstanbul Faculty of Medicine on February 3, 2020 after she had had a cerebrovascular disease. Although she retired from the age limit on September 9, 2010, she never had a break in outpatient clinics and surgeries, scientific studies, training activities and sharing her professional experiences until the day she fell ill.

Years ago she said to her students, "The first day you step into the faculty of medicine, you are students and you will spend your life given by God as students till the end of it." and she added, "When you say you are a professor and you know everything, you will be left behind. In medicine you must run all the time. You cannot stop." And she herself passed away without giving a break.

\section{Her Life}

Nermin Başerer was born in Fatsa, Ordu on September 9, 1943. With her own statement her father was a member of the first generation of an intellectual family migrating to Turkey from Batum during the Russian occupation.

She completed her primary and secondary school education in Fatsa as top of the class. With the support of her father who was one of the prominent tradesmen in Fatsa, with a bold decision according to the conditions in Turkey at that time, she went to a boarding school in İstanbul. In fact, she set her target to be a professor in the university in her primary school years with her father saying "I want my daughters to be a doctor and a professor at the university. She was a boarding student at İstanbul Kan-

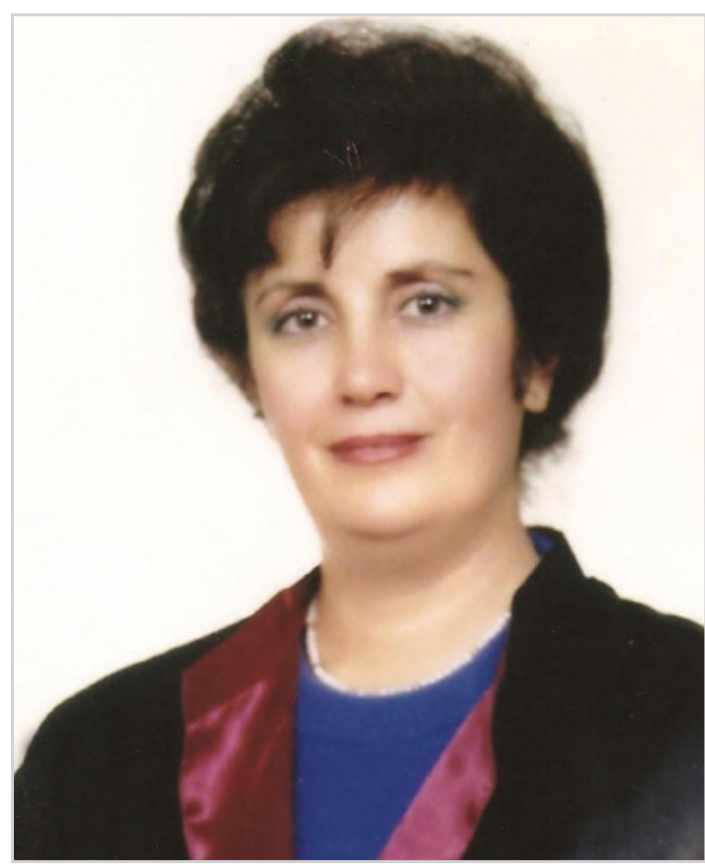

dilli High School between 1957-1960 and graduated from high school in degrees. Although she wanted to study architecture, which was a trending profession in those years, she started her medical education in İstanbul Faculty of Medicine in 1960 with the influence of her father and sister, Günçağ Dinçol, who is a hematology professor now and was a student at the same period.

In her first years at the university the advice that her physiology Professor Halil Derman gave, "If you want to be an architect instead, be a surgeon and make your wish come true in another way." led her in choosing the field of residency. 
She graduated from İstanbul Faculty of Medicine in 1966 and with the mentorship of her physiology professor, she started her residency training at the department of otorhinolaryngology (ORL) in the same faculty on August 1966 and became an ORL surgeon on August, 1969. The same year she started to work as a fellow in the same department. She worked in Croix Rousse Hospital in Lyon, France as a foreign resident for a year in 1973 and as a permanent resident for another year under the supervision of Dr. Jean Gaillard.

She became an associate professor with her thesis titled "The effects of psychoactive drugs on vestibular system" in 1976 and professor with her thesis titled "Etiological and Clinical Evaluation of Nasopharyngeal Cancers" in 1982. She served for 50 years in Istanbul Faculty of Medicine without interruption from 1960, until 2010 when she retired due to age restriction.

\section{Her Academic Life}

She was the first female associate professor and professor in the field of ORL in Turkey. She was also the first female chairman of the department of ORL between 1988 and 1991. Moreover, she was elected to be the first female president of the Turkish Otorhinolaryngology Head and Neck Surgery Society between 2006 and 2008. Her feelings about being the first female academician in Turkey: "I felt the happiness of being the first female professor of ORL when I see other female physicians take me as their role model. I have not encountered a bothersome difficulty being a female surgeon in the ORL clinic in Turkey. I experienced troubling events that are more common today not because I am female but as a doctor."

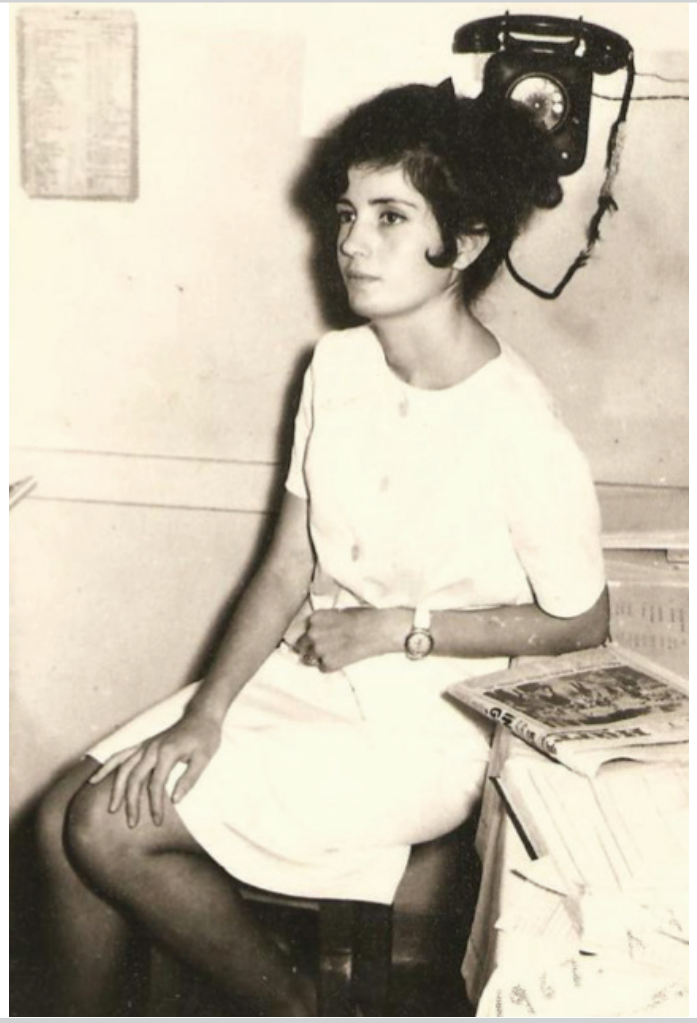

Figure 1. Nermin Başerer in the first year of ORL residency, 1966
She was especially interested in the fields of head and neck cancer surgery and otology. She started to be interested in hearing-impaired children in the second year of her residency, in 1968. With the mentorship of Professors Sefa Karatay and Behbut Cevanşir, she founded Burçin-Engin İnan Diagnosis and Training Center for the Hearing Impaired Children in 1979 and was the supervisor of it till she retired. She took part in the opening of Beyoğlu Halıcıoğlu Hearing Impaired Primary and Secondary School in 1990 with the joint protocol of İstanbul Municipality, İstabul Faculty of Medicine and the Ministry of Education. She received İstanbul University Scientific Research and Project Award in 2003, 2007 and 2009 because of her genetic studies on hearing impaired children.

As it can be understood from her associate professorship thesis which was on the vestibular system, her another field of interest was balance disorders, and she was supervising the vestibulometry unit from 1976 until her retirement. She was the most experienced surgeon in congenital aural atresia reconstruction in Turkey. She operated over 600 patients since 1976.

Her most important contribution to Turkish medicine was in the field of head and neck cancer surgery. She not only had her own operation techniques, but also contributed to the training of many ORL surgeons both in technical and philosophical aspects. Başerer tracheo-oesephageal shunt technique in the speech rehabilitation of the patients with total laryngectomy can be given as an example.

She tried to give many basic messages for her colleagues dealing with head and neck surgery including: avoiding mandibulotomy to increase exposure for benign parapharyngeal tumors and oral cavity cancers, pull-through resection for tongue cancers, emphasizing the effects of the involvement of the cricoid cartilage and anterior commissure on the prognosis of the larynx cancers.

Professor Nermin Başerer had more than 250 articles in Turkish, French and English, editorship for two chapters and authorship

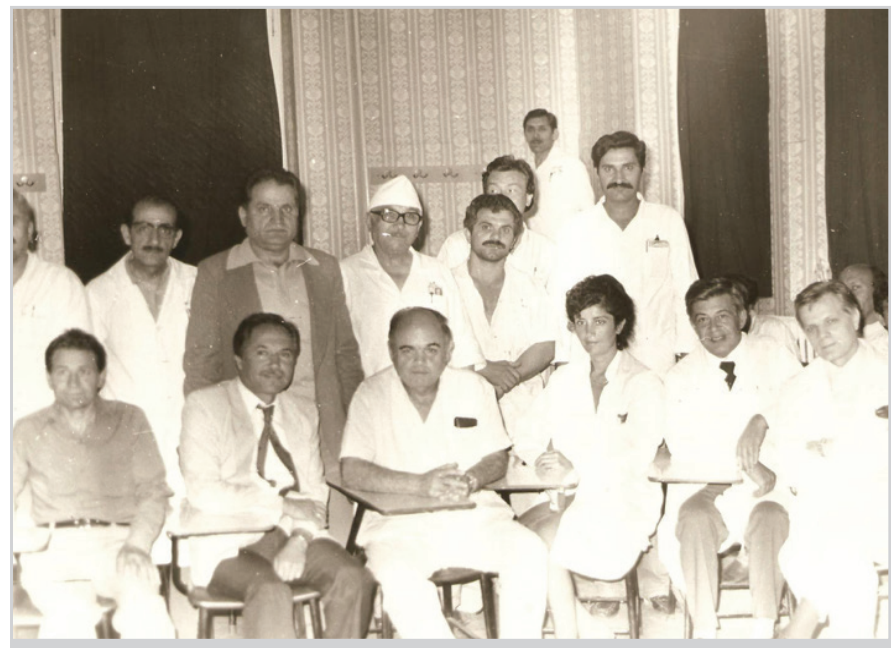

Figure 2. Associate Professor Nermin Başerer with her colleagues and residents in İstanbul Faculty of Medicine, 1978 


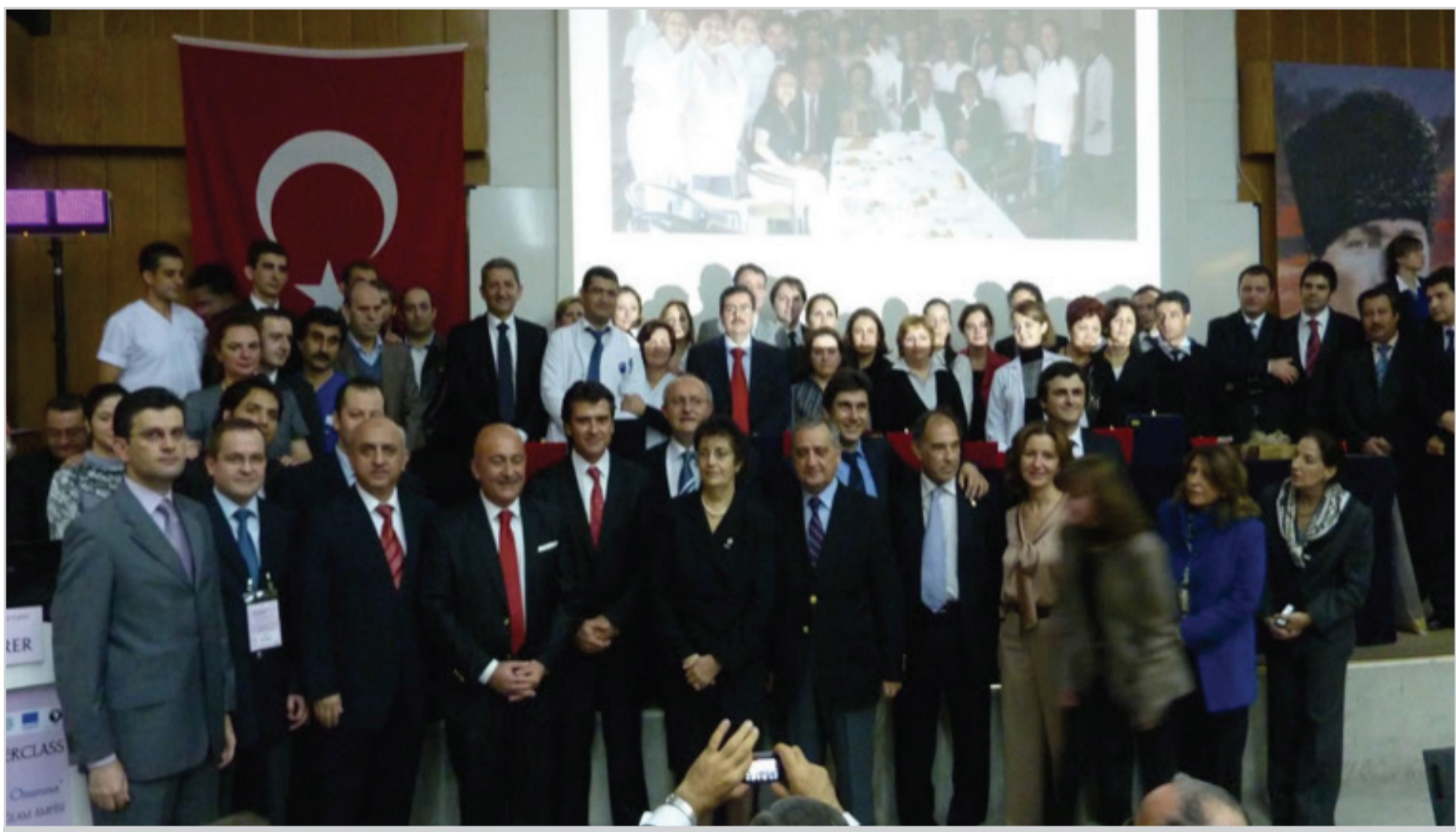

Figure 3. Retirement ceremony held for Professor Nermin Başerer, 2010

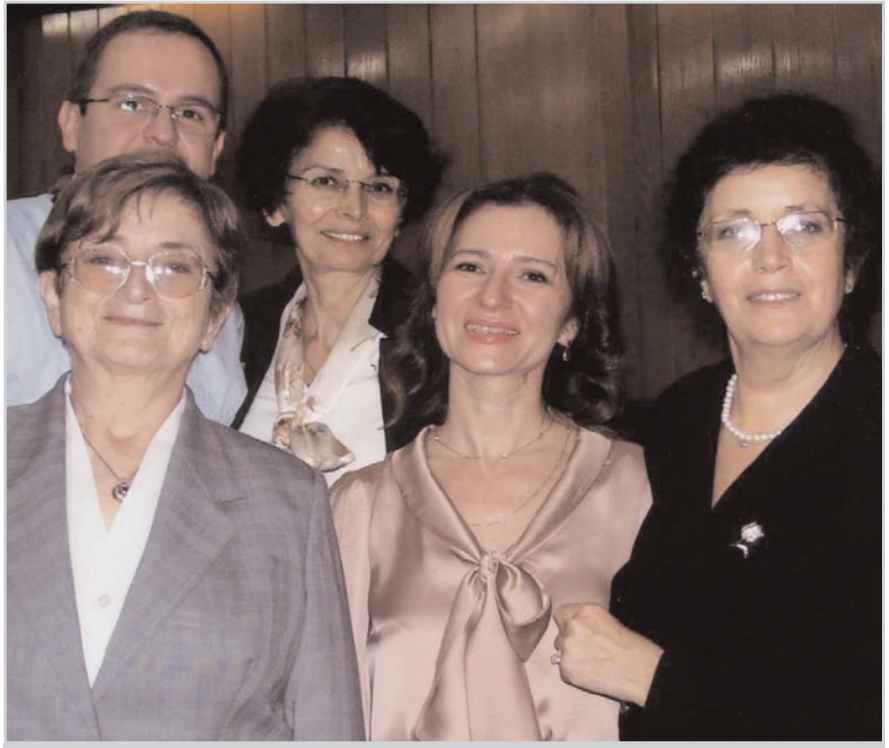

Figure 4.Professor Nermin Başerer with Professor Nesil Keleş Türel, Associate Professor Bora Başaran, her sisters Professor Günçağ Başerer Dinçol and Professor Tahire Başerer in her retirement ceremony, 2010

for five chapters in three books about otolaryngology and headneck surgery. She was the co-editor of the Turkish Journal of Ear Nose and Throat from the first publication year of 1990 until 2000 and editor in chief from 2000 until her death for 20 years.

\section{Her Philosophy}

Nermin Başerer was a very talented and agile surgeon with advanced knowledge of anatomy. The basic factors of her success were her intelligence, diligence and challenging personality. She

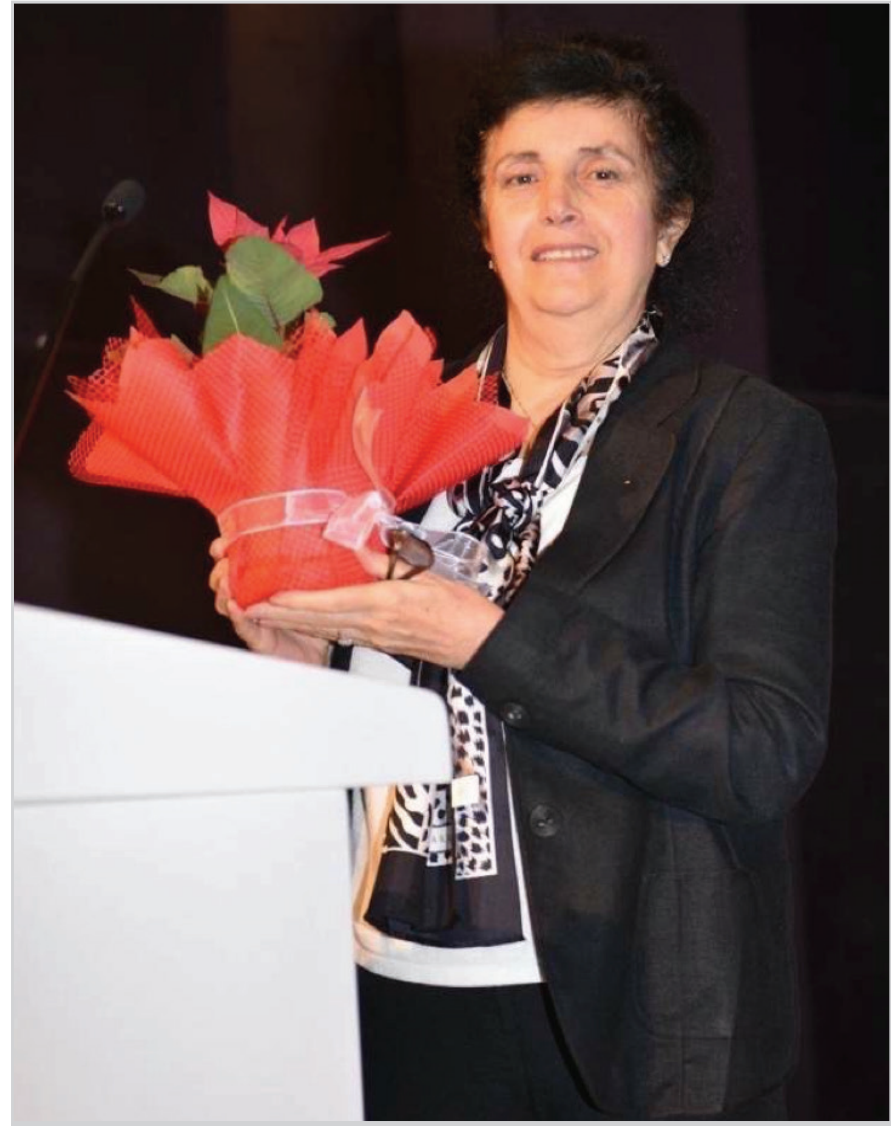

Figure 5. After her presentation about "Atatürk and woman" in the $40^{\text {th }}$ Turkish National Congress of Otorhinolaryngology, 2018

preferred working and producing instead of resting and pasttime activities. She used to say, "Whether I work or not, time flies 
away. At least I would like to have things that I have produced as time passes by."When she was in France, because of her speed and successful performance in the operations, her French colleagues named her as "Elle est diable" which means "She is a devil!" Besides many surgical techniques, she taught us to use our fingers as tools during dissections in the operations. During our residency, she always warned us and said, "Fingers are the third eye of a surgeon. Do not neglect to use them."

She always identified herself as a woman of the new Turkish Republic. She used to say that she came to this point owing to the reforms that Atatürk had provided to women. She used to tell that when she was in France, her mentor Professor Mouniere Kuhn said she was the daughter of Mustafa Kemal Atatürk and continued, "Atatürk is a great leader not only for our country, but also for the world. I'm honored to be a daughter of him, and this is encouraging for my studies."

She never got married and had no children. This does not mean that she was married to her profession. She was an outgoing person and a humanist. She accepted her residents as her own children and every time they were together she said, "bere, these are my children." As her residents we felt her maternal affection both during our residency and later on, especially in difficult times. While protecting our rights and defending us against unfair criticism, she used to criticize us in the hardest way when it was necessary. During our residency, she was the first person we asked for help and we always knew that she would always find a solution.

Professor Nermin Başerer, who was proud of being a member of the İstanbul University, İstanbul Faculty of Medicine, stated that it was an honor and chance to be in this faculty at all time. She served to thousands of patients with her professional experience and became an inspiration for her students, residents and colleagues with her diligence and determination.

May she rest in peace. 